\title{
Organizational Citizenship Behavior in Concern of \\ Communication Satisfaction: The Role of the Formal and Informal Communication
}

\author{
Nader Sheykh Al Eslami Kandlousi \\ School of Management, Universiti Sains Malaysia \\ 11800 Penang, Malaysia \\ E-mail: nader927@gmail.com \\ Anees Janee Ali \\ School of Management, Universiti Sains Malaysia \\ 11800 Penang, Malaysia \\ E-mail: aneesali15@yahoo.com \\ Anahita Abdollahi \\ School of HBP, Universiti Sains Malaysia \\ 11800 Penang, Malaysia
}

\begin{abstract}
Communication cues play an important role in the development of satisfaction within an organization. Communication in most of the related studies has been considered as a one-dimensional construct, while the present study specifically proposed formal and informal communication as predictors of communication satisfaction. Furthermore, although literature introduced job satisfaction as a great predictor of OCB, the present study takes one more step forward and proposes communication satisfaction as an antecedent of OCB. These relationships were tested by 231 survey completed by respondents from Electrical Manufacturing industry in Iran. Formal communication and informal communication were found to predict communication satisfaction. Besides, communication satisfaction was a strong predictor of all dimensions of OCB.
\end{abstract}

Keywords: Formal communication, Informal communication, Communication satisfaction, OCB

\section{Introduction}

Nowadays managers and scholars noticed the importance of organizational citizenship behavior (OCB) as a prerequisite for organizational accomplishment and effectiveness (Bolino \& Turnley, 2003; Zellars, Tepper, \& Duffy, 2002). Further, research found that satisfaction would motivate people to engage in OCB (Podsakoff, Mackenzie, Paine, \& Bacharach, 2000). In this line, numerous studies have been conducted on the relationship between job satisfaction and OCB (Bateman \& Organ, 1983; Foote \& Li-Ping Tang, 2008; Organ, 1988; Organ \& Konovsky, 1989; Vilela, González, \& Ferrín, 2008) while, no known research gave attention to the forecasting role of communication satisfaction on OCB. Therefore, one purpose of the present study is to fulfill the theoretical gap that exists in the relationship between communication satisfaction and employees' OCB.

On the other hand, communication as an antecedent of communication satisfaction (Carriere \& Bourque, 2009) in most of the studies is proposed as a one-dimensional construct, while mostly mentioned both formal and informal cues of communication (for exapmle see Carriere \& Bourque, 2009). The present study aims to determine the unique role of each of the formal and informal dimensions of communication on communication satisfaction.

2. Literature Review

Communication in General 
As defined by Duncan and Moriarty (1998), communication is a human activity that links people together and create relationship. In other word, each individual relates with other individuals by means of communication (Sanford, Hunt, \& Bracey, 1976). Cooren (1999) and Schwartzman (1989) suggested that communication constitutes the action of an organization and the works of organizing, coordinating, informing, arranging, subordinating and so on are carried out by communicative acts. The significant of communication is more than just information giving (Zhu, May, \& Rosenfeld, 2004). In fact communication has a vital role in failure, or accomplishment of any organization (Orpen, 1997).

In conceptualization of organizational communication, most of the researches focused on a one-dimensional construct of communication (for example see Anderson \& Narus, 1984; Carriere \& Bourque, 2009; Litterst \& Eyo, 1982), while they mentioned informal and formal figures of communication as common approach of communication practiced in an organizational setting (Anderson \& Narus, 1984; Carriere \& Bourque, 2009). Since, both formal and informal communication are essential to achieve communication satisfaction, the present study will focus on them separately.

\subsection{Formal Communication}

Formal communication channels are recognized officially by the organization. Instruction and information are passed downward and upward along these channels (Anderson \& Narus, 1984). Information in an organization provided by the formal communication makes managers' activities easier (Litterst \& Eyo, 1982). Formal communication follows the formal structure or hierarchy of the organization (Guffy, Rhoddes, \& Rogin, 2005). It can be upward, downward, or side-to-side directions of communications. Price (1997) defined formal communication as the degree to which information about job is transmitted by an organization to its member and among the members of an organization. By knowing the formal chart of an organization, a great deal of the nature of the communication flows within the organization is predictable (Evertt \& Rekha, 1976).

Formal communication has long been considered as the topic of research. Literature proposed that formal communication is related to productivity (Litterst \& Eyo, 1982), job satisfaction (Holtzhausen, 2002), decreases coordination costs (Sine, Mitsuhashi, \& Kirsch, 2006), reduce conflict, reinforce trust and overall satisfaction (Chio, Hsieh, \& Yang, 2004), and finally reduce the negative effects of rumors which lead to obtaining satisfaction (Difonzo \& Bordia, 2000).

\subsection{Informal Communication}

As well as the formal communication, informal communication also plays an inevitable role in an organizational life (Crampton, Hodge, \& Mishra, 1998). According to Homans (1951), existence of informal system in an organization is unavoidable because employees resist being treated as means to an end, and they interact as whole, bringing with them their own problems and purposes that give rise to spontaneous behavior that seek to control their condition of work (Ogaard, Marnburg, \& Larsen, 2008, p. 2). Colleagues during their interactions discover their similar attitudes, opinions, and values and consequently they become acquainted and mates to one another, which result in becoming friends (Hargie, Dickson, \& Nelson, 2003).

Informal communication is based on social relationship among people (Anderson \& Narus, 1984; Litterst \& Eyo, 1982; Guffy, Rhoddes, \& Rogin, 2005). Specifically, the origin of informal communication is "employees' private purposes" while the foundation of formal communication is supposed to serve the "purposes of the corporation" (Ogaard, Marnburg, \& Larsen, 2008). By having informal communication, employees can talk about their problems, attitudes, job, and whatever they like, which then lead to satisfaction. In addition, It is remarkable that informal communication would be an excellent source of information about employees' moral and problems that help managers to lead employees successfully (Guffy, Rhoddes, \& Rogin, 2005).

Gilsdorf (1998) and Daniels, Speaker, and Papa (1997) noted that informal channels of communication such as grapevine and gossip often fill the gaps that formal communication fails to address. They pronounced that, information that is transmitted through a formal system is either insufficient or ambiguous and informal system usually compensates these weaknesses. However, when employees are not obtaining sufficient information through the formal channels, then they rely on informal channels (Gray \& Laidlaw, 2002). Crampton, Hodge, and Mishra (1998) summarized that when employees feel threatened, insecure, under stress, and whenever a pending change exists, and ultimately, when communication from the management is limited, employees are found to be relying more on grapevine. Consequently, informal communication must logically affect on communication satisfaction since the most important role of informal communication is to fulfill the employees' informational needs. 


\subsection{Communication Satisfaction}

Organizations are oftentimes viewed in terms of their information flows and information processing capabilities (Tushman \& Nadler, 1978). Communication satisfaction in an organization can be described as a person's satisfaction with information flow and relationship variables within an organization (Nakra, 2006). The research of Downs (1990) and Downs and Hazen (1977) indicated that communication satisfaction is a multidimensional construct. These researchers defined the term as an individual's satisfaction with various aspects of communication in the organization.

\subsection{Communication and communication satisfaction}

In term of communication, evidences show that the more is better (Carriere \& Bourque, 2009). For example, research found that there was positive relationships between the amounts of time spend communicating and some important work outcomes like job satisfaction and the level of effort expended by employees (Yammarino \& Naughton, 1988). In fact, research showed that the communication practiced in an organization is related to, but not synonymous with communication satisfaction (Carriere \& Bourque, 2009). Considering the different roles of formal and informal communication on communication satisfaction, the present study hypothesized that:

H1: Formal communication is positively related to communication satisfaction.

H2: Informal communication is positively related to communication satisfaction.

\subsection{Organizational Citizenship Behavior (OCB)}

The origin of the field of OCB is going back to the early of 1980s decade when Bateman and Organ (1983) introduced the construct of OCB, by drawing upon concepts of supra-role behavior advanced by Katz and Kahn (1966). Organ (1988, p. 4) defined OCB "as a behavior that is discretionary, not directly or explicitly recognized by the formal reward system, and that in the aggregate promotes the effective functioning of an organization."

The original conceptualization of OCB (Bateman \& Organ, 1983; Organ, 1988), which was enclosed just extra role behavior has been modified by Organ in 1997. Factually, Morrison (1994) was the beginner of this trend who suggested that many OCB items might actually be covering behavior considered as in-role behaviors by employees and supervisors. Therefore, Organ (1997) added in-role behavior to the traditional definition of OCB, which was just contained of extra-role behaviors. He emphasized that no reference to extra-role behavior should be made when describing or defining OCB in the future (Organ, 1997). By this new conceptualization, OCB is considered as an aspect of job performance (Fisher, 2003; Koys, 2001).

Organ (1988) conceptualized OCB into five dimensions, namely, conscientiousness, sportsmanship, courtesy, civic virtue, and altruism. In explanation of these variables, he noticed that "conscientiousness" is a discretionary behavior of employees that exceed the minimum role requirements in organization. "Sportsmanship" refers to the willingness of employees to tolerant less ideal circumstances without complaining. "Courtesy" is another shape of discretionary behavior that prevents work-related problems with other employees. The person who shows "civic virtue", participate responsibly in, is involved in, or is concerned about the life of the company. Finally, "altruism" is a discretionary behavior of helping others in organizationally related task or problem (Organ, 1988).

\subsection{Communication satisfaction and $O C B$}

Satisfaction and happiness are suggested to be positively related to better performance (Fisher, 2003). Specifically, communication satisfaction has been found that affect on job performance (Goris, 2007). As Fisher (2003) and Koys (2001) noted, OCB is an aspect of job performance. Therefore, it can be concluded that communication satisfaction in work environment is positively related to $\mathrm{OCB}$, which is an aspect of job performance. However, the main motive of the relationship between communication satisfaction and OCB is prescribed in the social exchange theory. This theory argues that people reciprocate the advantages that they receive from their organization. In other word, if employees are satisfied, then, they try to reciprocate by engaging in OCB (Bolino, 1999). In numerous researches, social exchange theory has been used as the primary theory to explain why employees perform OCB (Konovsky \& Pugh, 1994; Lambert, 2000; Organ, 1988; Bowler, 2006). Therefore, we hypothesized that:

$\mathrm{H} 2$ : Communication satisfaction is positively and significantly related to of $O C B$. 
The proposed theoretical framework of the present study is as bellow:

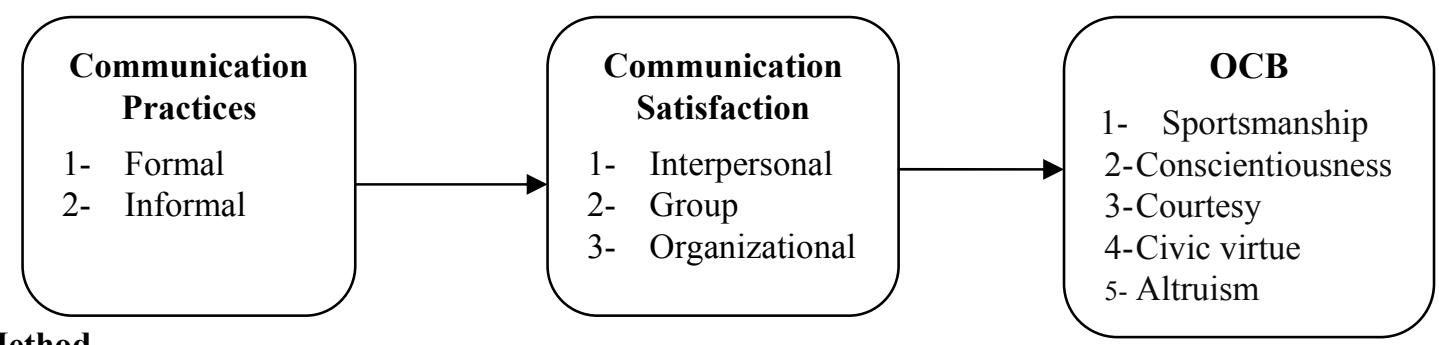

\section{Method}

\subsection{Sample}

The focus organizations for this study were the large Electrical Manufacturing Companies in Iran and the sample of the study at hand was consisted of two levels that are the supervisory and employee (worker) level with individual as the unit of analysis.

Set "A" of the questionnaire, which measured formal and informal communication and communication satisfaction, was completed by the workers and set "B" of the questionnaire, which aimed to measure the OCB of the subordinates, was completed by their direct supervisors. First, questionnaire set "A" was provided together with an envelope to the workers. Then, we asked them to complete the questionnaire and put the completed questionnaire into the envelope, sealed the envelope and wrote their names on the envelope. By completing this procedure, we made them sure that their answers would be totally kept secret. Subsequently, they submitted the completed questionnaire to their direct supervisors. The direct supervisors were asked to complete one set questionnaire of set "B". In fact, set "B" had to be answered by the supervisors according to one specific person by referring to the name that was written on the envelope. Then, they attached the completed set " $\mathrm{B}$ " together with set " $A$ " and returned them to the researcher.

Of the 1000 surveys (set " $\mathrm{A}$ ") distributed, 348 were returned to the researchers, for a response rate of $34 \%$. Out of 348 questionnaires set "A", just 316 were attached with a completed questionnaire of set "B" (complete by supervisors). Some employee surveys were returned without names (13 sets) and some supervisors failed to evaluate some employees (32 cases). In addition, some of both group respondents (set "A" and "B") returned uncompleted surveys (77 questionnaires set "A" and 8 questionnaires set "B"). Therefore, the matching process reduced the number of usable surveys to 231 .

\subsection{Measures}

3.2.1 Formal and informal communication: This part of the survey is a self-construct measurement. Based on a vast review of the existing literature at the scope of communication, a set of items were created for the two dimensions of communication that are, formal and informal. These items reflect the formal and informal approach of communication process in an organization based on the definitions conceptualized in the literature review. In general, a total number of 23 items were developed with 12 items measure informal communication dimension and 11 items measure the formal communication dimension. Then, each of the items was scaled on a five-point scale ranging from 1 to 5 . Number 1 indicating "strongly disagree" and number 5 pointing out of "strongly agree".

To purify the items, the measurement was submitted to a number of experts in the area of management and organizational science to be evaluated. By this process, the researcher would be able to make sure of the validity of the measurement. The revised version of the measurement was distributed among 25 management master students of Islamic Azad University, the Ghemshahr Branch in Mazandaran province to make a pre-test. The twice-revised version of the measurement then, was distributed among 20 employees of a tax office in Iran (specifically, in the city of Chalous). The employees were asked to identify the items that were confusing and difficult to understand. In the abovementioned stages, some items were revised and in total two items were deleted.

At the final stage, 150 questionnaires, which consist of the measurement, was distributed among employees of tax offices at the west of Mazandaran province in Iran. 112 completed questionnaires were returned. Factor analysis was used to determine the appropriate items. From the process of factor analysis, 3 items were deleted and the rest of the items fall into two categories, which were named as formal and informal dimensions of communication. 
3.2.2 Communication Satisfaction: The Communication Satisfaction Questionnaire (CSQ), developed by Downs and Hazen (1977), was used to assess employee satisfaction with internal communication. Traditionally, this measure consists of 40 items covering eight dimensions: (1) communication climate; (2) communication with supervisors; (3) organizational integration; (4) media quality; (5) horizontal and informal communication; (6) organizational perspective; (7) personal feedback; and (8) communication with subordinates.

Mueller and Lee (2002), based on definitions of these eight dimensions of communication satisfaction, divided them into three categories: interpersonal, group, and organizational context. According to their classification, personal feedback, supervisory communication, and subordinate communication are placed in interpersonal context of communication satisfaction (Mueller \& Lee, 2002). Group context encompasses co-workers communication and organizational integration and finally corporate communication, communication climate, and media quality are situated in organizational context of communication satisfaction (Mueller \& Lee, 2002). This classification because of comprehensiveness, high number of users and easiness to use is taken as underlying conceptualization of communication satisfaction at the present study.

3.2.3 OCB: The last part of the questionnaire, which measured OCB, was adopted from a study of Podsakoff, Mackenzie, Moorman, and Fetter (1990). Since employee's supervisors have been the better source of choice to obtain their employees rating of OCB (for instances see Bateman \& Organ, 1983; Organ \& Konovsky, 1989; Podsakoff et al., 1990), the present research has used the proposed measurement by Podsakoff, Mackenzie, Moorman, and Fetter's (1990) to get hold of employees rate of OCB. The items included in this scale were based on the definitions of the five dimensions of OCB described by Organ (1988), namely, (1) conscientiousness; (2) sportsmanship; (3) courtesy (4) civic virtue; (5) altruism.

\subsection{Result}

The findings indicate that on the issue of gender, the sample was predominantly male with $68.8 \%$ compared to female $31.2 \%$. Most of the respondents were aged between 30 to 39 ( 43.3 percent) years old. The respondents' marital status showed that a large number (73.2\%) were married, while it was followed by $19 \%$ were single and $7.8 \%$ divorced respondents. All respondents were in the production position and regarding the tenure, $43.3 \%$ of the respondents had 11 to 15 years job experience.

\subsubsection{Factor analysis of the formal and informal communication}

Eighteen items were used to measure the communication comportment in terms of formal, informal dimensions. In sum, five items were removed to enhance the measurement of communication in the following process of data analysis. Finally, the principal component analysis with varimax rotation churned out two factors with Eigenvalues greater than 1.0 . These two factors explain $63.74 \%$ of the total variance. The KMO measures of sampling adequacy stood at .92 indicating sufficient intercorrelations while the Bartlett's Test of Sphericity was significant (Chi Square $=1734.18$ ).

The first factor was measuring informal communication was with nine items that after factor analysis reduced to seven items. Formal communication was the second factor of the measurement and started with nine items, which after factor analysis lost three items and reduced to six items. The result of factor analysis and reliability is shown in the table 1.

\subsubsection{Factor analysis of the communication satisfaction}

The result of factor analysis for the communication satisfaction indicated three factors solution with Eigenvalues greater than 1.0 and the total variance experienced was $60.99 \%$ of the total variance. KMO measure of sampling adequacy was .94 indicating sufficient intercorrelations while the Bartlett's Test of Sphericity was significant (Chi square $=4586.99$ ). The result of factor analysis and reliability analysis is presented in the table 1 .

\subsubsection{Factor analysis of the Organizational Citizenship Behavior}

The result of factor analysis of the OCB indicated a 5-factor solution with Eigenvalues of 10.92 to 1.07 (greater than 1.0). All items of the five components had factor loading of above 5.6. It means that the cut-off point of 40 (Hair et al., 2006) was fulfill. The total variance explained was $70.53 \%$ of the total variance. KMO measure of the sampling adequacy was .90 indicating sufficient intercorrelations while the Bartlett's Test of Sphericity was significant (Chi square 4069.64). Four factors of the fifth factors consist of 5 items and one factor consists of 4 items. Results are shown in table 1.

\subsection{Correlations}

Descriptive and zero-order correlations are presented in table 2. As shown, there were positive and strong relationships (with double stars $* *$ ) between two dimensions of communication (informal and formal) with the 
three dimensions of communication satisfaction (interpersonal, group, and organizational dimensions). The positive correlation between formal and informal communication with three dimensions of communication satisfaction offer some support for Hypotheses 1. Furthermore, the inter-correlation between all dimensions of communication satisfaction with all dimensions of OCB were positive and proper which shows some basic support for the third hypothesis 2 of the present study.

\subsection{Multiple regression analysis}

Communication to communication satisfaction: At the first regression analysis model, interpersonal dimension of communication satisfaction was the dependent variables and all dimensions of organizational communication (formal and informal) were independent variables.

In the second model, group dimension of communication satisfaction was dependent variable and in the third model organizational dimension of communication satisfaction was the dependent variable while in both models organizational dimensions of communication (formal and informal) were the independent variables. A summary of all regression models is presented in Table 3 .

In all three models $R^{2}$ shows that dependent variables can properly predicted by independent variables. The results showed that informal communication was stronger in predicting interpersonal dimension of communication satisfaction (St. Beta .54, p <.05) than formal communication (St. Beta .20, p <.05). If informal communication is a consistent feature of an electrical manufacturing company it is likely that employees would have opportunities to discuss their personal matters, and enjoy closer interpersonal relationships, which probably lead to employees' satisfaction in term of interpersonal communication. The next predictor of interpersonal communication satisfaction is formal communication. Formal communication with providing information regarding to the work issues will enhance employees' interpersonal communication satisfaction.

At the group level of communication satisfaction, it was found that, formal communication is the stronger predictor (St. Beta $.25, \mathrm{p}<.05$ ) than informal communication (St. Beta $.15, \mathrm{p}<.05$ ). It is logical that peoples' feeling about group activities would be well shaped by the formal communication provided by the organization.

Formal communication also found to be a better predictor of organizational dimension of communication satisfaction (St. Beta .41, p <.05) than informal one (St. Beta $.30, \mathrm{p} \leqslant .05$ ). It is to be expected that information and communication from the formal communication procedure of organization would be associated with satisfaction of communication in organizational level.

Communication satisfaction to $O C B$ : To run the regression analysis between dimensions of communication satisfaction and OCB dimensions, 5 models were shaped (since we had 5 dependent variables - OCB dimensions). At the first model, all dimensions of communication satisfaction were independent variable and first dimension of OCB (sportsmanship) was the dependent variable. At the second model, the second dimension of OCB (conscientiousness) was the dependent variable and at the third, forth, and fifth model courtesy, civic virtue, and altruism were the dependent variables. A summary of all regression models on the relationship between communication satisfaction and OCB is presented in Table 6.

The results revealed that all models are properly fit and in all models dependent variable appropriately predicted by independent variables. The result also disclosed that organizational dimension of communication satisfaction is the strongest predictor of sportsmanship (St. Beta .53, p<.05). It followed by interpersonal dimension of communication satisfaction, which has the second strongest predictability of sportsmanship (St. Beta .24, p<.05) while group dimension of communication had the weakest contribution in predicting sportsmanship (St. Beta .18, $\mathrm{p}$ <.05). Sportsmanship refers to the willingness of employees to tolerant less ideal circumstances without complaining. Regarding to the findings of the present research, if employees are satisfied of the organizational dimension of communication satisfaction more probably tolerant less ideal organizational circumstances without complaining. Perhaps, organizational level of communication satisfaction will motivate people to be satisfied of the whole organization therefore, they engage in sportsmanship.

Organizational dimension of communication satisfaction also had the highest rate on predicting of conscientiousness (St. Beta .62, p <.05) and interpersonal dimension had the lowest rate in predicting conscientiousness (St. Beta .14, p <.05). Conscientiousness is a discretionary behavior of employees that exceed the minimum role requirements in organization. The result highlighted that if employees are satisfied by organizational level of communication they will reply to the organization by exceeding their minimum role requirements.

Courtesy is another shape of discretionary behavior that prevents work-related problems with other employees. Organizational dimension of communication satisfaction had the highest amount of predictability of this variable 
(St. Beta $.51, \mathrm{p}$.05), which shows that employees reciprocate to the organization by preventing work-related problems. Another issue that looks to be important is that if organizational communication provides enough information will definitely prevent work related problems. Interpersonal dimension (St. Beta .30, p<.05) and group dimension (St. Beta .22, $\mathrm{p} 3.05$ ) had the following position in predicting courtesy.

In predicting civic virtue, group dimension was the strongest predictor (St. Beta $.30, \mathrm{p}<.05$ ) which is followed by interpersonal dimension (St. Beta $.28, \mathrm{p}<.05$ ) and organizational dimension (St. Beta $.24, \mathrm{p}<.05$ ) of communication satisfaction. Civic virtue is defined as participate responsibly in, or concern about the life of the company. Interpersonal dimension of communication satisfaction deals with personal feedback, supervisory communication, and subordinate communication. As we found in the previous part, interpersonal dimension of communication satisfaction was strongly predicted by informal communication. Therefore, it is understandable that the issues like life of the company are more transmitted by informal communication than the formal one.

Altruism is a discretionary behavior of helping others in organizationally related task or problem. This sense of helping others is originated from sense of belonging to the group. As it is found in the present study, group dimension of communication satisfaction was the strongest predictor of employees' altruism (St. Beta .43, $\mathrm{p}<.05$ ) than other dimensions of communication satisfaction.

At whole, the result of the present study is in line with Podsakoff and his colleagues (2000) that categorized satisfaction as the most important antecedent of OCB at the individual level since employees' communication satisfaction is a consideration of satisfaction in an organizational setting.

In general, theories and practices are not vast in offering empirically or theoretically investigations on the relationship between communication satisfaction and OCB. Concerning of the importance role of satisfaction on predicting $\mathrm{OCB}$, the concentration of the previous research existed only on job satisfaction. Even, some research (Organ \& Konovsky, 1989) proposed job satisfaction as the most dominant element in predicting OCB. The present study considers communication satisfaction, as well as job satisfaction, would contribute to predict OCB. Findings of the present study demonstrate that the issues associated with OCB and communication satisfaction were mostly in line with our justification and previous studies. Meanwhile, one of the major purposes of the present study is to strengthening the usefulness of the social exchange theory. The findings of the present study highlight the potency of social exchange theory in practice. Regarding to this theory, employees reciprocate the advantages that receive from their organization (Bolino, 1999). Therefore, we would argue that they would engage in $\mathrm{OCB}$ to reciprocate the sense of satisfaction that they received from the organizational communication approach.

\section{Conclusion}

In light of the present research's findings highlighted earlier, several implications are considered. From the theoretical perspective, the present research has enriched the literature on the integration of a few distinct bodies of knowledge such as communication (formal and informal), communication satisfaction and OCB. The present study has certainly broadened the understanding formal and informal communication as indicators of employees' communication satisfaction, as well as OCB and its predictors. There is no doubt concerning the lack in the literatures and practices in the scope of communication satisfaction and OCB. The present study is a modest attempt to clarify this gap and fulfill this space in the scope of theoretical perspective. Therefore, scholars and practitioners are encouraged to catch this opportunity and strive to highlight more on this issue.

All this while, OCB has been taken as a key organizational behavior that leads to organizational accomplishment. Therefore, it would be a major concern for managers to amplify employees' participation in OCB. The present study would like to suggest to managers and practitioners to pay attention to the motives that generate positive attitudes among organizational members. Positive attitudes will motivate employees to engage in OCB (Koys, 2001; Bolino, 1999). One easy way to achieve positive attitude is through communication practices. If employees are satisfied with the communication process in their organization, they will gradually obtain positive attitudes toward their communication pattern. Because this sense of satisfaction (positive attitude) originates from their organization, then they will try to reciprocate to the company by engaging in OCB.

Overall, the findings of the present study would provide valuable insight for management to adopt various and effective tools in their workplace. To achieve firm missions and objectives and to obtain and maintain competitive advantages, managers and decision makers should act and apply effective communication process. Employees in any organization need to know their job duties and responsibility clearly, before they can proceed with their allocated assignments. In addition, the informal form of communication would be an inevitable part of any organization. If the formal process of communication, which is an important figure of an organization, does not provide adequate information to their employees, employees then will turn to the informal form of 
communication. The relational needs of people will push them to accomplish informal connection with others. This has to be observed with precautions since some of the informal forms of communication are not $100 \%$ correct and could be misleading. It is the responsibilities of managers to handle and manage this form of communication since too much utilization of informal communication will damage employees' satisfaction. Reversely, too less use of informal communication process in an organization will also harm their satisfaction in the communication process.

Although the present study has successfully provided some interesting findings and made important contributions regarding the relationship between communication, communication satisfaction and $\mathrm{OCB}$, it also has some shortcomings.

The data of the present study was collected from electrical manufacturing companies in Iran, which may limit the generalizability of the results to the other industries. In addition, most of the respondents were working at electrical manufacturing companies, which are located in Tehran, the capital city of Iran. The different and unique working cultures in a big city like Tehran further limit the generalization of the present study. Another limitation of the present research is that it explores the respondents from the workers level only. Since the workers level of the company are the lowest level employees in the companies, their level of communication satisfaction may be different from their supervisors and managers. Lastly, the present study is a cross sectional rather than a longitudinal study and the results may have provided less depth in understanding than a longitudinal study would. In addition, the present study is purely quantitative in nature. Future research may supplement the present study with qualitative studies that use focus groups and observations.

\section{References}

Anderson, J. C., \& Narus, J. A. (1984). A model of the distributor's perspective of distributor-manufacturer working relationships. Journal of Marketing, 48(4), 62-74.

Bateman, T. S., \& Organ, D. W. (1983). Job satisfaction and the good soldier: The relationship between affect and employee "citizenship". Academy of Management Journal, 26(4), 587-595.

Bolino, M. C. (1999). Citizenship and impression management: Good soldiers or good actors? The Academy of Management Review, 24(1), 82-98.

Bolino, M. C., \& Turnley, W. H. (2003). Going the extra mile: Cultivating and managing employee citizenship behavior. Academy of Management Executive, 17(3), 60-71.

Bowler, W. M. (2006). Organizational goals versus the dominant coalition: A critical view of the value of organizational citizenship behavior. Institute of behavioral and applied management , 258-273.

Brownell, J. (1990). Management: Grab hold of the grapevine. Cornell Hotel \& Restaurant Administration Quarterly, 31(2), 78-83.

Carriere, J., \& Bourque, C. (2009). The effects of organizational communication on job satisfaction and organizational commitment in a land ambulance service and the mediating role of communication satisfaction. Career Development International, 14(1), 29-49.

Chio, B. J., Hsieh, C. H., \& Yang, C. H. (2004). The effect of franchisors' communication, service assistance, and competitive advantage on franchisees' intentions to remain in the franchise system. Journal of Small Business Management, 42(1 , 19-36.

Cooren, F. (1999). The Organizing Property of Communication. Amsterdam: John Benjamins.

Crampton, S. M., Hodge, J. W., \& Mishra, J. M. (1998). The informal communication network: Factors influencing grapevine activity. Public Personnel Management, 27(4), 569-584.

Daniels, T. D., Speaker, B. K., \& Papa, M. J. (1997). Perspectives of Organizational Communication. Dubuque: Brown and Benchmark.

Difonzo, N., \& Bordia, P. (2000). How top PR professionals handle hearsay: corporate rumors, their effects, and strategies to manage them. Public Relation Review, 26(2), 173-190.

Downs, C. W., \& Hazen, M. D. (1977). A factor analytic study of communication satisfaction. The Journal of Business Communication, 14(3), 63-73.

Downs, C. M. (1990). Predicting of communication satisfaction during performance apprisal interviews. Management Communication, 3(3), 334-354. 
Duncan, T., \& Moriarty, S. E. (1998). A communication-based marketing model for managing relationships. Journal of Marketing, 62(2), 1-13.

Evertt, M. R., \& Rekha, A. R. (1976). Communication in Organizations. New York: Free Press.

Fisher, D. C. (2003). Why do lay people believe that satisfaction and performance are correlated? Possible sources of a commonsense theory. Journal of Organizational Behavior, 24(6), 753-777.

Foote, D. A., \& Li-Ping Tang, T. (2008). Job satisfaction and organizational citizenship behavior (OCB); Does team commitment make a difference in self-directed teams? Management Decision, 46(6), 933-947.

Gilsdorf, J. W. (1998). Organizational rules on communicating; how employees are and are not learning the ropes. Journal of Business Communication, 35(2), 173-201.

Goris, J. R. (2007). Effects of satisfaction with communication on the relationship between individual-job congruence and job performance/satisfaction. Journal of Management Development, 26 (28), 737-752.

Gray, J., \& Laidlaw, H. (2002). Part-time eployment and communication satisfaction in an Australian retail organization. Employee Relations, 24(2), 211-228.

Guffy, M. E., Rhoddes, K., \& Rogin, P. (2005). Business Communication. Toronto: South- Western.

Hargie, O., Dickson, D., \& Nelson, S. (2003). Working together in a divided society, a study of intergroup communication in the Northern Ireland workplace. Journal of Business and Technical Communication, 17(3), 285-318.

Hecht, M. L. (1978). Measures of communication satisfaction. Human Communication Research, 4(4), 350-368.

Holtzhausen, D. (2002). The effect of divisionalised and decentralized organizational structure on a formal internal communication function in a south Africa organization. Journal of Communication Management, 6(4), 323-339.

Homans, G. C. (1951). The Human Group. London: Routledge \& Kegan Paul.

Katz, D., \& Kahn, R. (1966). The Social Psychology of Organization. New York: Wiley.

Konovsky, M. A., \& Organ, D. W. (1996). Dispositional and contextual determinants of organizational citizenship behavior. Journal of Organizational Behavior, 17(3), 253-266.

Konovsky, M. A., \& Pugh, S. D. (1994). Citizenship behavior and social exchange. Academy of Management Journal, 37(3), 656-669.

Koys, D. J. (2001). The effects of employee satisfaction, organizational citizenship behavior, and turnover on organizational effectiveness: a unit-level, longitudinal study. Personnel Psychology, 54(1) , 101-114.

Lambert, S. J. (2000). Added benefits: The link between work-life benefits and organizational citizenship behavior. Academy of Management Journal, 43(5), 801-815.

Litterst, J. K., \& Eyo, B. (1982). Gauging the Effectiveness of formal communication programs: a search for the communication- productivity link. Journal of Business Communication, 19(2), 15-26.

Moorman, R. H. (1991). Relationship between organizational justice and organizational citizenship behaviors: Do fairness perceptions influence employee citizenship? Journal of Applied Psychology, 76(6), 845-855.

Morrison, E. W. (1994). Role definitions and organizational citizenship behavior: The importance of the employe's perspective. Academy of Management Journal, 37(6), 1543-1567.

Mueller, B. H., \& Lee, J. (2002). Leader-member exchange and organizational communication satisfaction in multiple contexts. The Journal of Business Communication, 39(2), 220-244.

Nakra, R. (2006). Relationship between communication satisfactionand organizational identification: an empirical study. The Journal of Business Perspective, 10(2), 41-51.

Nur, Y. A. (2003). Management-by-virtues: a comparative stud of sprituality in workplace and its impact on selected organizational outcome. PhD. Dessertation. Indiana: Indiana University.

Ogaard, T., Marnburg, E., \& Larsen, S. (2008). Perception of organizational structure in the hospitality industry: Consequences for commitment, job satisfaction and perceived performance. Tourism management, 29(4), 661-671.

Organ, D. W. (1997). Organizational citizenship behavior: It's construct clean-up time. Human Performance, 10(2), 85-97. 
Organ, D. W. (1988). Organizational Citizenship Behavior: The Good Soldier Syndrome. Lexington, MA: Lexington Books.

Organ, D. W., \& Konovsky, M. A. (1989). Cognitive versus affective determinants of organizational citizenship behavior. Journal of Applied Psychology, 74(1), 157-164.

Orpen, C. (1997). The interactive effects of communication quality and job involvement on managerial job satisfaction and work motivation. The Journal of Psychology, 131(5), 519-522.

Podsakoff, P. M., Mackenzie, S. B., \& Boomer, W. H. (1996). Transformational leader behaviors and substitute for leadership as determinants of employees satisfaction, commitment, trust, and organizational citizenship behaviors. Journal of Management, 22(2), 259-298.

Podsakoff, P. M., Mackenzie, S. B., Moorman, R. H., \& Fetter, R. (1990). Transformational leader behaviors and their effects on followers trust in leader satisfaction and organizational citizenship behavior. Leadership Quarterly, 1(2), 107-142.

Podsakoff, P. M., Mackenzie, S. B., Paine, J. B., \& Bacharach, D. G. (2000). Organizational citizenship behavior: A critical review of the theoretical and empirical literature and suggestions for future research. Journal of Management, 26(3), 513-563.

Price, J. L. (1997). Handbook of organizational measurement. International Journal of Manpower, 18(4/5/6), 303-558.

Sanford, A. C., Hunt, G. T., \& Bracey, H. J. (1976). Communication Behavior in Organization. Columbus: Bell \& Howell Company.

Schwartzman, H. B. (1989). The Meeting: Gatherings in Organizations and Communities. New York: Plenum.

Sine, W. D., Mitsuhashi, H., \& Kirsch, D. A. (2006). Revisiting Burns and Stalker: formal structure and new venture performance in emerging economic sectors. Academy of Management Journal, 49(1), 121-132.

Tushman, M., \& Nadler, D. (1978). Information processing as an integrating concept in organizational design. Academy of Management Review, 3(3), 613-624.

Vilela, B. B., González, J. A., \& Ferrín, P. F. (2008). Person-organization fit, OCB and performance appraisal: Evidence from matched supervisor-salesperson data set in a Spanish context. Industrial Marketing Management, 37(8), 1005-1019.

Yammarino, F. J., \& Naughton, T. J. (1988). Time spent communicating: a multiple levels of analysis approach. Human Relations, 41(9), 655-676.

Zellars, K. L., Tepper, B. N., \& Duffy, M. K. (2002). Abusive supervision and subordinate organizational citizenship. Journal of Applied Psychology, 87(6), 1068-1076.

Zhu, Y., May, S. K., \& Rosenfeld, L. B. (2004). Information adequacy and job satisfaction during merger and acquisition. Management Communication Quarterly, 18(2), 241-270.

Table 1. Factor solution for all variables

\begin{tabular}{lccc}
\hline \multicolumn{1}{c}{ Factor name } & Number of items & Eigenvalues & Reliability $\boldsymbol{\alpha}$ \\
\hline Communication & & & \\
Formal Communication & 6 & 3.70 & .87 \\
Informal Communication & 7 & 4.58 & .90 \\
Communication Satisfaction & & & \\
Personal dimension & 12 & 6.99 & .93 \\
Group dimension & 7 & 4.60 & .89 \\
Organizational dimension & 9 & 5.43 & .92 \\
OCB & & & \\
Sportsmanship & 5 & 3.63 & .87 \\
Conscientiousness & 5 & 3.46 & .86 \\
Courtesy & 5 & 3.44 & .88 \\
Civic virtue & 4 & 3.31 & .87 \\
Altruism & 5 & 3.07 & .87 \\
\hline
\end{tabular}


Table 2. Inter-Correlation of Research Variables

\begin{tabular}{|c|c|c|c|c|c|c|c|c|c|c|}
\hline & 1 & 2 & 3 & 4 & 5 & 6 & 7 & 8 & 9 & 10 \\
\hline \multicolumn{11}{|l|}{ 1- Informal Communication } \\
\hline 2- Formal Communication & $55^{* *}$ & & & & & & & & & \\
\hline $\begin{array}{l}\text { 3- Interpersonal dimension of } \\
\text { communication satisfaction }\end{array}$ & $.65^{* *}$ & $.50 * *$ & & & & & & & & \\
\hline $\begin{array}{l}\text { 4- Group dimension of } \\
\text { communication satisfaction }\end{array}$ & $.29^{* *}$ & $.33^{* *}$ & $.44 * *$ & & & & & & & \\
\hline $\begin{array}{l}\text { 5- Organizational dimension of } \\
\text { communication satisfaction }\end{array}$ & $.53 * *$ & $.58^{* *}$ & $.67 * *$ & $.57^{* *}$ & & & & & & \\
\hline 6-Sportsmanship & $.41 * *$ & $.38 * *$ & $.59^{* *}$ & $.55^{* *}$ & $.63^{* *}$ & & & & & \\
\hline 7-Conscientiousness & $.38 * *$ & $.32 * *$ & $.46^{* *}$ & $.51^{* *}$ & $.53 * *$ & $.50^{* *}$ & & & & \\
\hline 8-Courtesy & $.49 * *$ & $.45^{* *}$ & $.67 * *$ & $.63^{* *}$ & $.80 * *$ & $.67 * *$ & $.61 * *$ & & & \\
\hline 9-Civic virtue & $.44 * *$ & $.32 * *$ & $.47^{* *}$ & $.50^{* *}$ & $.51^{* *}$ & $.44^{* *}$ & $.55 * *$ & $.46^{* *}$ & & \\
\hline 10-Altruism & $.32 * *$ & $.23 * *$ & $.47 * *$ & $.55^{* *}$ & $.52 * *$ & $.53 * *$ & $.66 * *$ & $.61 * *$ & $.64 * *$ & \\
\hline
\end{tabular}

Note: *Significant at $0.01 ; * *$ Significant at 0.05

Table 3. Standardized Beta for the communication and communication satisfaction

\begin{tabular}{|c|c|c|c|}
\hline$\overbrace{\text { IVs }}^{\text {DVs }}$ & $\begin{array}{c}\text { Interpersonal Dimension } \\
\text { of communication } \\
\text { satisfaction }\end{array}$ & $\begin{array}{c}\text { Group dimension of } \\
\text { communication } \\
\text { satisfaction }\end{array}$ & $\begin{array}{c}\text { Organizational dimension } \\
\text { of communication } \\
\text { satisfaction }\end{array}$ \\
\hline Formal Communication & $.203 * *$ & $.252 * *$ & $.418^{* * *}$ \\
\hline Informal Communication & $.543 * * *$ & $.153^{*}$ & $.305 * * *$ \\
\hline$R^{2}$ & .45 & .12 & .40 \\
\hline $\mathrm{F}$ value & $96.46 * * *$ & $16.92 * * *$ & $78.66^{* * *}$ \\
\hline
\end{tabular}

Table 4. Standardized Beta for the communication satisfaction and OCB

\begin{tabular}{|l|c|c|c|c|c|}
\hline IVs DVs & Sportsmanship & Conscientiousness & Courtesy & Civic virtue & Altruism \\
\hline $\begin{array}{l}\text { Interpersonal dimension of } \\
\text { communication satisfaction }\end{array}$ & $.24^{* * *}$ & $.14^{* * *}$ & $.30^{* * *}$ & $.28^{* * *}$ & $.21^{* * *}$ \\
\hline $\begin{array}{l}\text { Group dimension } \\
\text { communication satisfaction }\end{array}$ & $.18^{* * *}$ & $.26^{* * *}$ & $.22^{* * *}$ & $.30^{* * *}$ & $.43^{* * *}$ \\
\hline $\begin{array}{l}\text { Organizational dimension of } \\
\text { communication satisfaction }\end{array}$ & $.53^{* * *}$ & $.62^{* * *}$ & $.51^{* * *}$ & $.24^{* * *}$ & $.22^{* * *}$ \\
\hline$R^{2}$ & .73 & .84 & .81 & .48 & .54 \\
\hline $\begin{array}{l}F \text { value } \\
* * * \mathrm{p}<.000\end{array}$ & $74.61^{* * *}$ & $43.66^{* * *}$ & $194.58^{* * *}$ & $40.58^{* * *}$ & $48.52^{* * *}$ \\
\hline
\end{tabular}

